\title{
ETHNIC ASPECTS OF SETTLEMENT IN IUS VALACHICUM \\ IN MEDIEVAL POLAND \\ (FROM THE 14TH TO THE BEGINNING OF THE 16TH CENTURY)
}

\author{
GRZEGORZ JAWOR
}

\begin{abstract}
The purpose of this article is to present the relationships which occurred between the settlement of numerous villages on the Wallachian law in the mountainous regions of Medieval Poland and the influx of settlers representing the Wallachian ethnos in this area. Without doubt, both Poles and Ruthenians could not play a decisive role in this process for they did not have the essential skills related to the economic exploitation of mountains, and they were particularly not able to conduct a pastoral economy on a mass scale. They were also not able to independently adapt the forms of social organisation of villages, which were specific for the Wallachian law. The Vlachs, pouring into the studied area throughout the 14th to 16th centuries, were arguably not numerous, but they played a key role in organising new settlements in the mountains. A particularly significant role in this process was played by the chiefs of the Wallachian villages-knyazes (knezes). They had adequate knowledge, financial possibilities as well as administrative and judicial power over the rest of the people in order to become a group, which, on the one hand, was disseminating the Wallachian law, and on the other hand, was consequently standing up for the Wallachian law which was beneficial to them. Even though they relatively quickly underwent assimilation processes and integration with the local surroundings, losing their original ethnic distinctiveness, the Wallachian law was still being spread. In that way, it turned from being an ethnic law into a symbol of privileging all people who were using it, regardless of their ethnicity.
\end{abstract}

Grzegorz Jawor, professor, Maria Curie Skłodowska University, Insitute of History, Plac Marii Curie-Skłodowskiej 4A, 20-031 Lublin, Poland, e-mail: grzegjaw@poczta.onet.pl

Keywords: medieval Poland, Ius Valachicum, Vlachs migrations, knezes, ethnos.

DOI: http://dx.doi.org/10.14746/bp.2015.22.4

It is beyond doubt that one of the most important tendencies in the last few years in the studies of the Ius Valachicum (Wallachian law) on the northern slopes of the Carpathians is the almost universal recognition of the participation in this process of the immigrants who represented the Wallachian ethnos. The conclusions of Kazimierz Tymieniecki and Kazimierz Dobrowolski are particularly important here. According to these scholars, the spread of the Wallachian law could not take place analogically to the case of typically rural German law (Ius Alemanicum), which could have been used and introduced everywhere, in relation to every group of farmers, irrespective of their nationality, without the need of participating in this process of the reforms of the "ethnic" bearers of a new custom. The difficulty with applying the Wallachian law to the farmers stemmed from the need of abandoning their past achievements, limiting or discarding the farming of land for the purpose of activities associated with breeding 
on a so-far unprecedented scale. ${ }^{1}$ Without an impulse in the form of the arrival in these areas, subjected to such reforms, of foreign people who had the necessary knowledge, this thorough change of their current lifestyle was rather unthinkable.

The oldest phase of the settlement, tangible in the sources, took place in Poland in the periods of the fourteenth and fifteenth centuries and is described as a result of the migration of the Wallachian ethnos from the areas of Moldova, Transylvania and Transcarpathia, undergoing very fast processes of integration and assimilation with the local element, Eastern-Slavic and much more rare - Slovak or Polish. Particularly the oldest settlement current from the south, dating to the fourteenth century, is characterised as significant. ${ }^{2}$ Similar views are also present in Czech, Slovak and even Ukrainian literature, so far very critically approaching the notion of a visible presence of the Wallachian element in the vast areas of the Eastern and Western Carpathians. ${ }^{3}$

${ }^{1}$ Kazimierz Dobrowolski, „Zderzenie kultury rolniczej z pasterską” [Collision between Agricultural and Pastoral Culture], Sprawozdania z Czynności i Posiedzeń PAU, no 5 (1939, printing: 1945): 192; Kazimierz Tymieniecki, Historia chłopów polskich, vol. 2: Schyłek średniowiecza [History of Polish Peasants, vol. 2, The Decline of the Middle Ages], (Warszawa: Państwowe Wydawnictwo Naukowe, 1966), 434.

${ }^{2}$ Dobrowolski, „Studia nad kulturą pasterską w Karpatach północnych. Typologia wędrówek pasterskich od XIV-XX wieku", [Studies on the Pastoral Culture in the Northern Carpathians. Typology of Pastoral Migrations from the 14th to the 20th century], Wierchy 29 (1960): 104; Ireneusz Ichnatowicz et al., Spoteczeństwo polskie od X do XX wieku [Polish Society from the 10th to the 20th century], (Warszawa: Książka i Wiedza, 1988), 104; Tadeusz M. Trajdos, „Początki osadnictwa Wołochów na Rusi Czerwonej" [The Beginnings of the Settlement of the Vlachs in Red Ruthenia], in: Łemkowie w historii i kulturze Karpat, ed. Jerzy Czajkowski, part 1, (Rzeszów: Muzeum Budownictwa Ludowego w Sanoku, 1992), 199 - 210; Andrzej Janeczek, Osadnictwo pogranicza polsko-ruskiego. Województwo betskie od schytku XIV do poczatku XVII w. [The Settlement in the Polish-Ruthenian Borderland. Betż Voivodeship from the End of the 14th century to the Beginning of the 17th century], (Wrocław: Zakład Narodowy im. Ossolińskich, 1991), 146, 150, 173; Michał Parczewski, „Początki napływu ludności ruskiej na teren Karpat Zachodnich w świetle archeologii” [The Beginnings of the Influx of the Ruthenians to the Western Carpathians in the View of Archaeology], Archaeologia Historica 18 (Brno 1993): 93; Adam Fastnacht, Osadnictwo ziemi sanockiej w latach 1340-1650 [The Settlement of the Land of Sanok between 1340 and 1650], (Wrocław: Zakład Narodowy im. Ossolińskich, 1962), 218 -220; Henryk Samsonowicz, „Grupy etniczne w Polsce w XV wieku” [Ethnic Groups in Poland in the 15th century], in: Ojczyzna bliższa $i$ dalsza. Studia historyczne ofiarowane Feliksowi Kirykowi w sześćdziesiata rocznicę urodzin, ed. Jacek Chrobaczyński, Andrzej Jureczko, Michał Śliwa, (Kraków: Wydawnictwo i drukarnia „Secesja”, 1993), 462. Specific examples of the migrations of the Vlachs onto the territories of the medieval Red Ruthenia and Lesser Poland (Małopolska) were given by me in the following works: Grzegorz Jawor, "Sur la provenance territoriale des immigrés valaques dans le royaume de Pologne (XIVème s. - début du XVIème s.)", Banatica, 23 (2013): 545 - 554; idem, "Etniczny aspekt osadnictwa wołoskiego na przedpolu Karpat w Małopolsce i Rusi Czerwonej ( XIV - XV)" [The Enthic Acpect of the Wallachian Settlement on the Outskirts of Lesser Poland and Red Ruthenia $\left(14^{\text {th }}-15^{\text {th }}\right.$ c.) ], in: Poczqtki sqsiedztwa. Pogranicze polsko - rusko - slowackie w średniowieczu. Materiaty z konferencji - Rzeszów 9-11 V 1995, ed. Parczewski, (Rzeszów: Mitel, 1996), $301-306$.

${ }^{3}$ Cf. Jawor, Aşezările de drept valah şi locuitorii lor din Rutenia Roşie în Evul Mediu târziu. (Jaşi: Editura Universității Alexandru Ioan Cuza, 2013), 27 - 32; or the Polish edition of the same monograph: Osady prawa wołoskiego i ich mieszkańcy na Rusi Czerwonej w późnym średniowieczu. [The Settlements of the Wallachian Law and their Inhibitants in Red Ruthenia in the Late Middle Ages]. Second edition: complemented, (Lublin: Wydawnictwo UMCS, 2004), 17 - 20. 
While the existence of the "ethnic" Vlachs in the areas already discussed has been widely accepted and no longer triggers lively arguments, the question concerning the number of immigrants remains unanswered. An obstacle in undertaking this problem appears in the form of not only the lack of sources, but also the huge dispersion of the preserved information. They can be encountered particularly in the hundreds of surviving, handwritten judicial and taxation volumes from the areas of Małopolska (Lesser Poland) and Red Ruthenia, which are currently stored in Polish and Ukrainian archives and libraries. Such a query is extremely time-consuming and the results obtained through it are usually very modest. For the Wallachian law covered very peripheral areas, distant from the contemporary political and cultural centres, so the places where the writing was commonly used. Even the Wallachian settlers did not have this skill and the $14^{\text {th }}-15^{\text {th }}$ centuries is a period when a document still did not displace in everyday practise, particularly in the lower social strata, the oral testimonies of witnesses or relying on the collective memory as a means for proving one's rights or claims. These very few preserved, and concise in their content, records concerning the Wallachian settlers are the work of court scribes - usually Poles, who did not understand the specificity of the Wallachian law or who often attempted to identify the elements of this legal practice with the local concepts. This "office Polonization" of various concepts, or even the names of the Wallachian settlers, makes it even more difficult for a modern historian to undertake research which would be promising in terms of obtaining satisfactory results. It is impossible to even attempt to approach the problem in statistical terms basing it on the references in sources regarding individuals, small groups of people or the events associated with their existence. In return, there are ambiguous and vague terms such as "numerous", "few", "significant", etc. or, equally risky in their effects, a formulation of scholarly opinions based on general impressions and feelings of a scholar, which do not correspond with a scientific description. ${ }^{4}$

To the exceptional situations should be also included information from the sources, which allow for a more resolute phrasing of the thesis on the large influx of the

${ }^{4}$ I.e. Trajdos defined the percent of ethnic Vlachs in Subcarpathian settlements in the $14^{\text {th }}-15^{\text {th }}$ centuries as "small, but visible" (idem, Głos w dyskusji [Voice in Discussion], in: Łemkowie w historii, part 1, 392); for Tymieniecki it was a "significant" contribution (idem, Historia chłopów, 433); it is similarly evaluated by Dobrowolski ("Studia nad nazwami miejscowymi Karpat Polskich" [Studies on the Local Names of the Polish Carpathians], Sprawozdania z Czynności i Posiedzeń PAU, no 8 (1930): 1). Fastnacht (Osadnictwo, 222) refers to the migration influx from the south as "strong"; for Roman Reinfuss ("Łemkowie w przeszłości i obecnie" [Lemkos in the Past and Now], in: Łemkowie. Kulturasztuka-język. Materiaty z sympozjum zorganizowanego przez Komisję Turystyki Górskiej ZG PTTK. Sanok dn. 21-24 091983 r, (Warszawa-Kraków: PTTK Kraj 1987, 10) the Balkan ethnic element flowing in to Poland was very humble in terms of numbers, but it played an important role in shaping the material and spiritual culture in the entire Carpathian area. By contrast Jerzy Strzelczyk („Ku Rzeczpospolitej wielu narodów i wyznań. Katolicy i prawosławni w późnośredniowiecznej Polsce" [Towards the Commonwealth of Many Nations and Religions. Catholics and Orthodox in the Late Middle Age Poland], Sredniowiecze polskie i powszechne, 1 (1999): 162-164) writes about enclaves inhabited by ethnic Vlachs, placed in the territories of Lesser Poland (Małopolska) and Red Ruthenia. 
Wallachian population to the areas of Pokucie since the problem of these cross-border migrations became a hotbed of conflict between Poland and Moldova between the fifteenth and the sixteenth centuries.

In this case, the written sources correspond to the findings of linguists of the ancient Romanio-Ruthenian bilingualism amongst the inhabitants of the area. ${ }^{5}$ The general impression of the significant influx of immigrants most of all derives from the extent of the area of Małopolska (Lesser Poland) and Red Ruthenia where ius Walachicum occurred and the references to people described as Vlachs. This statement corresponds with research conducted since the mid-nineteenth century by linguists, who found and interpreted hundreds of words of Romanian origin in the areas, which is very important for our deliberations because they fully overlap with the range authenticated by the sources, ius Valachicum. At this point, however, it is necessary to make valid claims, significantly undermining the usefulness of these types of sources for our needs. There is no consensus amongst linguists regarding which types of personal and area names or a common vocabulary were the result of migration and which were indirectly borrowed. Even though the oldest Wallachian toponyms were solidified by the Polish sources dated to the fourteenth century, the vast majority of the material is a result of field research conducted in the nineteenth and twentieth centuries. Therefore, there is no certainty, which Romanian words were brought by the medieval Wallachian settlers and which arrived in the Polish territories much later, as a result of being part of the Polish and Romanian lands under the rule of the Habsburgs. ${ }^{6}$

${ }^{5}$ I discussed the problem of migration in Pokucie more broadly in the following works: Jawor, Sur la provenance territoriale, idem, Osady, 30 -33. Amongst linguists' works regarding this area this should be mentioned in particular: Stefan Hrabec, Nazwy geograficzne Huculszczyzny [Geographic Names of Hutsulshchyna], (Kraków, Polska Akademia Umiejętnosci, 1950), 54 - 56, 234 and Jan Janów, "Wpływ słownictwa rumuńskiego na Podkarpacie, osobliwie na gwarę huculską" [The Influence of the Romanian Vocabulary on Subcarpathia, Peculiarly on the Dialect of Hutsulshchyna], Sprawozdania Towarzystwa Naukowego we Lwowie, 16 no 1 (1938): 21.

${ }^{6}$ This problem was more broadly discussed in Jawor, Osady, $34-37$. Amongst the rich onomastic literature for the purpose of our discussion the following works should be mentioned: Dobrowolski, Studia nad nazwami, 1 - 5; idem, „Studia nad pochodzeniem ludności pasterskiej w Karpatach Zachodnich” [Studies on the Origins of the Pastoral Population in the Western Carpathians], Sprawozdania z Czynności i Posiedzeń PAU, no 6 (1951): 478 - 486; idem, „Studia nad kulturą pasterską w Karpatach północnych. Typologia wędrówek pasterskich od XIV-XX wieku" [Studies on the Pastoral Culture in the Northern Carpathians. The Typology of the Pastoral Migrations from the 14th to the 20th century], Wierchy, 29 (1960): 23 - 26; Władysław Lubaś, Nazwy miejscowe południowej cześsi dawnego województwa krakowskiego [The Local Names of the Southern Part of the Former Cracow Voivodeship], (Wrocław: Zakład Narodowy im. Ossolińskich, 1968); Janusz Rieger, Nazwy wodne dorzecza Sanu [The names of the San River Basin Waters], (Wrocław: Zakład Narodowy im. Ossolińskich, 1969); idem, "Toponomastyka Beskidu Niskiego i Bieszczadów Zachodnich" [Toponomies of the Low Beskids and the Bukovec Mountains], in: Lemkowie. Kultura-sztuka-język, Witold Truszkowski, Studia socjolingwistyczne z dialektologii rumuńskiej. Na materiale wsi Dragu w Siedmiogrodzie rumuńskim w konfrontacji z polska gwara wsi Ochotnica Dolna w Gorcach [The Socio-linguistic Studies in the Romanian Dialectology. On the example of Dragu Village in the Romanian Transylvania Confronted by the Polish Dialect in Ochotnica Dolna Village in Gorce], (Kraków: Uniwersytet Jagielloński, 1992); Józef Bubak, „Nazwy 
With the current state of knowledge, it is difficult for an unambiguous decision whether, in the case of the Wallachian migrations, we are dealing with a trend of elite or mass migrations. The former is characterized by the movement of small groups of people in a direction leading from the centre of civilization to more backward areas. In the case of mass migration we are dealing with an opposite situation based on the movements of large groups of people wandering from the periphery toward civilization centres. As in the case of other social facts, also this division is very schematic since it does not include many situations when the described migration contains the threads of both these trends. ${ }^{7}$ These modern concepts are also not adequate to the description of reality from centuries ago. Just as it is difficult to recognize areas of medieval Moldova and Transylvania as being preeminent territories, it would be also a misconception to treat the Kingdom of Poland as a periphery towards the former areas. The issue can be treated differently if by the centre we will understand only the area, which is preeminent in terms of the development of the mountainous areas, unavailable for the farmers, by conducting in their territories alternative activities for so far on an unknown scale (mainly pastoral activities, but also linked to the exploitation of forests or different branches of food processing and handicrafts). In this sense, the immigrants from the Romanian areas had at their disposal, knowledge and experience, which were unavailable and at the same time highly attractive for a Polish or Ruthenian peasant. Most likely it was in this Wallachian instrumentation, which the ius Vallachicum included and which was so far unknown to the local population, where the hidden secret was placed. It was the settlement trend spreading across the vast areas of the Carpathians and the Balkans, reaching further to the islands in the Mediterranean and then Asia Minor. Ilona Czamańska very accurately expressed the aspect of this discussed problem at the end of one of her popular works:

the undoubted descendants of the Vlachs, the Romanians, persistently searching for their roots amongst the famous ancient nations, not always recognizing that this modest, for a long time illiterate, people in the sheepskin coats and sheepskin kacziulas, did one thing more important for the European civilization than creating the political powers- they tamed the mountains. ${ }^{8}$

As much as the disseminators of the Wallachian law in its oldest phase, dated to the fourteenth century, were the immigrants of first or second generations, then in the subsequent centuries the placement of new villages was being done more often on the basis of the local element, deriving from the old Wallachian settlements. Even though

osobowe mieszkańców Zakopanego (nazwiska, przydomki, przezwiska i imiona)" [Personal Names of the Inhabitants of Zakopane (Surnames, Nicknames, Monikers and Names)], in: Zakopane. Czterysta lat dziejów, ed. Renata Dutkowa, (Kraków: Krajowa Agencja Wydawnicza,1991).

${ }^{7}$ Stanisława Golinowska, ,Teoria migracji a debata o swobodzie przepływu w rozszerzonej Unii Europejskiej" [The Theory of Migration vs. The Debate on Freedom of Movement in the Extended European Union], Problemy polityki społecznej. Studia i dyskusje, no 3 (2001): 18 (further literature on this matter therein).

${ }^{8}$ Ilona Czamańska „Wołosi - strażnicy gór” [Vlachs- the Guardians of Mountains], in: Kalendarz 2014. informacje pasterskie. Od Owcy Plus do Redyku Karpackiego 2013, (Fundacja Pasterstwo Transhumancyjne, 2013): 33. 
the migrations from the areas of Romania did not stop, they were also not decisive in the extraordinary expansion of this settlement, dated in the mountainous areas only to the sixteenth century. In the most well-recognised lands of Sanok, there were around 158 villages encompassed by the Wallachian law until 1650 . In the $16^{\text {th }}$ and at the beginning of the $17^{\text {th }}$ century $80 \%$ of them were created while the remaining $20 \%$ belonged to the older initiatives. ${ }^{9}$

Therefore a question remains concerning the circle of people who acted as the leaders of this legal custom and who handed over its principles to the younger generation and initiated the formation of new villages. There is no doubt that they were knezes (Polish: kniaziowie) - the chiefs of the Wallachian settlements or members of their families. It is impossible at this point to provide a closer characterisation of this most typical institution in the Wallachian custom and the readers concerned with this matter should be referred to the passages of a repeatedly cited monograph of mine. ${ }^{10}$ At this point I would limit myself to saying that their legal privilege, but also the high, hereditary and material wages as well as the judicial, administrative and even religious authority (placing family members in the offices of priests in the local Orthodox churches) over the humble inhabitants of villages subordinated to them, caused the knezes to have suitable financial resources and the knowledge necessary for organizing new villages. At the same time it was a group most interested in defending the conditions of the ownership and existing powers, particularly because of the frequent threats from the owners of the villages at the beginning of the $16^{\text {th }}$ century. On all the Polish lands encompassed by the Wallachian colonization, the same pattern is constantly repeated: the knezes of the older Wallachian villages or the members of their families located new settlements so that after some time they became a starting point for further settlement initiatives. ${ }^{11}$

The maintenance of the position of the knezes families was often favoured due to the characteristics of this social group. Very often the specific members of the family remained with each other in a property communalism called inaction (niedziat). It was characterised by a significant, since it was extending over several generation, durability and a significant number of co-shareholders as its consequence. This condition can

\footnotetext{
${ }^{9}$ Fastnacht, Osadnictwo, 267.

${ }^{10}$ Jawor, Osady, 128 - 148; idem, Aşezările de drept valah, 152 - 173.

${ }^{11}$ Ludwik Wyrostek, „Ród Dragów-Sasów na Węgrzech i Rusi Halickiej” [The House of Drag-Sas in Hungary and Halych Ruthenia], Rocznik Polskiego Towarzystwa Heraldycznego, 11: (1932), 145; Edmund Długopolski, „Przyczynki do osadnictwa wołoskiego w Karpatach” [The reasons for the Wallachian Settlement in the Carpathians], in: Odb. ze Sprawozdania Filii c.k. Gimnazjum św. Jacka w Krakowie za rok 1916, (Kraków, by author, 1916): 6; Czajkowski, „Dzieje osadnictwa historycznego na Podkarpaciu i jego odzwierciedlenie w grupach etnicznych" [The History of the Historical Settlement in Subcarpathia and Its Reflection in the Ethnic Groups], in: Eemkowie w historii, 155; Fastnacht, Osadnictwo, 155; Jawor, „Pierwsze pokolenia mieszkańców wsi bieszczadzkich w XIV-XVI w. (Pochodzenie etniczne i terytorialne.)" [The First Generations of the Inhabitans of Villages in Bieszczady in the 14th-16th centuries (Ethnic and Territorial Origins)], in: Narodziny Rzeczypospolitej. Studia z dziejów średniowiecza i czasów wczesnonowożytnych, vol. I, ed. Waldemar Bukowski and Tomasz Jurek, (Kraków, Societas Vistulana, 2013): 567-582.
} 
be explained by both the economic and social rationale. They protected the individual participants from losing a privileged position in a rural community and from being pushed out to the role of peasants. It also hindered the possibility of buying out the knezes state or its part by strangers. The communal management also made it easier to survive in times of crisis. ${ }^{12}$ Just as in the case of the humble nobility of the Wallachian origin, the sources indicate the knezes' reluctance to enter any closer relationships with the local surroundings or to search for marriage partners within the local group. ${ }^{13}$ There is no doubt that these privileged immigrants generally within 2-3 generations would lose their ethnic distinctiveness by blending into the local environment. These processes took place particularly quickly in the areas there the Orthodox religion was dominant. It was the Orthodox Church which linked the Vlachs with the Ruthenian environment while the Slavic language was a language of liturgy for them. ${ }^{14}$ At some point in the history of the settlement located on the Wallachian law the feeling of being different became supplanted by an equally strong belief in the need for maintaining local separation, which was after all guaranteeing a privileged position of, particularly, the knezes (more frequently referred to as provosts, soltysi) in comparison to the situation of the local population. ${ }^{15}$ For example, in the village of LubyczaKniazie (a former province of Bełz), existing still in the $19^{\text {th }}$ century, the knez said that their ancestors once rescued a Russian prince (meaning, a kniaź), hiding him from the Tatars'. To return the favour, he forever exempted them from any duty, he gave them land and the authority of princes. ${ }^{16}$ It is beyond doubt that a story constructed

12 Maria Koczerska in the work: Rodzina szlachecka $w$ Polsce późnego średniowiecza [Aristocratic Family in Poland in the Late Middle Ages], (Warszawa, Państwowe Wydawnictwo Naukowe, 1975): 102.

13 In the village Lubycza-Kniazie, situated in the former voivodeship of Bełz, communalism functioned from the first half of the $15^{\text {th }}$ century to the mid- $19^{\text {th }}$ century and eventually reached a number of around 200 Jawor, „Elity osad prawa wołoskiego na Rusi Czerwonej. Przemiany i trwanie (na przykładzie wsi Lubycza w województwie bełskim od XV do połowy XIX w.)" [The Elites of the Wallachian Law Settlement in Red Ruthenia. Changes and Duration (With an Example of Lubycza Village in Betz Voivodeship from the 15th to the middle of the 19th century)], Średniowiecze Polskie i Powszechne, 3(7): (2011): $227-241$.

14 The issues of assimilation and integration of the Vlachs with the local environment were given more attention in the following works: Jawor, "Współistnienie grup etnicznych na Rusi Czerwonej w XVXVI wieku na przykładzie stosunku do społeczności wołoskich" [The Coexistence of Ethnic Groups in Red Ruthenia from the $15^{\text {th }}$ to the $16^{\text {th }}$ century with an Example of Attitude towards the Wallachian Populations], Annales UMCS, sectio F. Historia, 52/53, (1997/1998): 53-65; idem, Osady, 167 - 181 (Aşezările de drept valah, 195 - 211.)

15 Czajkowski, Dzieje osadnictwa, 156; Janeczek, Osadnictwo pogranicza, 184 - 186; Zofia HołubPacewiczówna, Osadnictwo pasterskie $i$ wędrówki w Tatrach i na Podtatrzu [Pastoral Settlement and Migrations in the Tatra Mountains and Sub-Tatras], (Kraków, Polska Akademia Umiejętności, 1931): 273; Stanisław Kuraś, „Osadnictwo i zagadnienia wiejskie w Gorlickiem do połowy XVI w.” [Pastoral Settlement and Migrations in the Tatra Mountains and Sub-Tatras], in: Nad rzekq Ropq. Szkice historyczne, (Kraków, Wydawnictwo Literackie, 1968): 70 - 72.

16 Андрій Лунів, „Любича-Князі”. Причинки до історії сіл волоського права в Галичини” [Andrij Luniv, „Knyazi Lubich”. Comments to the History of Wallachian Law in Galicia], Записки Наукового товариства імени Шевченка, 150, (1929): 93. 
in such a way legitimised their unique, yet constantly threatened, legal and economic position, but at the same time it denoted a complete obliteration of knowledge regarding the true origin of the inhabitants. Depending on the local conditions, the traces of the original Vlachs' ethnos became consolidated by, more or less, a legible manner in the form of vocabulary (especially in relation to pastoral activities), elements of beliefs, rituals and material culture. The ethnographers wandering in the $19^{\text {th }}$ century in the Polish mountains saw (or perhaps wanted to see) the distinctiveness of even the anthropological nature of the descendants of the knezes. This is how Szczęsny Morawski described the inhabitants of historical Łemkowszczyzna:

To this day, it is not difficult to distinguish a grey-eyed, fair-haired and slow Ruthenian peasant from a black-haired, active Wallachian provost. ${ }^{17}$

These processes were carried out differently in the case of the remaining inhabitants of the Wallachian villages, who did not belong to the already discussed dominant group. The natural consequence of the desire of both knezes and the Wallachian village owners to increase the income deriving from them was to gather under their authority a maximum number of dependent populations. The economic calculation resulted in allowing the local population, mostly representing the Ruthenian ethnos, for the settlements within their borders. This phenomenon, known from preserved sources which date back to the $15^{\text {th }}$ century and wasintensified in the next century. However, the law was notoriously broken, prohibiting the local population to settle in the Wallachian villages. Despite the threat of punishment, fugitives from other estates were also used. During this time, the expansion process of the Ruthenian element to the areas previously occupied by the Vlachs grew rapidly. It is no exaggeration to state that at the territories close to the Carpathians a collision took place between the numerically dominant, and those coming from the East, Ruthenian population and the Vlachs. What could come into play was an escape from the numerous and devastating Tatars invasions between the $15^{\text {th }}$ and $16^{\text {th }}$ centuries, but also a fact of leaving by the Ruthenian peasants the villages governed by the Ruthenian custom due (ius Ruthenicum) to the excessive duties expected from the owner, which resulted from the rules imposed on them by the Ruthenian custom. ${ }^{18}$

As a consequence, many villages situated at the foothills faced a rather complicated situation: the authority was kept in them by the knezes families, undoubtedly of

17 Szczęsny Morawski, Sądecczyzna za Jagiellonów z miasty spiskiemi i księstwem oświęcimskim [The Land of Sacz during Jagiellonian Dynasty with the Towns of Spiš and the Duchy of Oświęcim] vol. 2, (Kraków, by author, 1865): 300. Similar comments were made by Maksymilian Gumplowicz, „Polacy na Wegrzech" [The Poles in Hungary], Lud, 6, (1900): 366 and Władysław Pulnarowicz, U źródet Sanu, Stryja i Dniestru. (Historia powiatu turczańskiego) [At the Waters of San, Stryi and Dniester. (The History of the District of Turka)], (Turka n/Sanem, Wydawnictwo Związku Strzeleckiego, 1929): 19.

18 Jawor, Ryszard Szczygieł, „Pogranicze Słowiańszczyzny zachodniej i wschodniej w późnym średniowieczu i czasach nowożytnych" [The Borderland of Western and Eastern Slavdom in the Late Middle Ages and Modern Times], in: Geograficzne problemy pogranicza Europy zachodniej i wschodniej, ed. Henryk Maruszczak and Zdzisław Michalczyk, (Lublin, Wydawnictwo UMCS, 2004): 61-72. 
Wallachian origins, but despite their conservatism they underwent an inevitable process of assimilation with the locals. The inhabitants of these settlements could have been the descendants of the Wallachian immigrants (as can be seen from the analysis of often single sources), who were subjected to pressure by the Ruthenian population settling there en masse. Interestingly, defending the principles of Wallachian law was primarily but not exclusively a matter for the knezes. It suffices to mention here that the villagers in these settlements had lower tributes and rents than often their neighbours from the farm-land villages (useing ius Alemanicum, ius Polonicum or ius Ruthenicum). They also did not have to perform feudal services for the owner as it was unknown to Wallachian law. Paradoxically, in this way the disappearance of the Wallachian ethnos was accompanied by the creation of a community of people of different origins, but connected with each other through the willingness of maintaining legal privilege, acquired from the first inhabitants. Probably at this time the word Vlach lost its original ethnical context and came to mean a legal or professional community. It was from that moment on that the new chapter in the history of the settlement based on Wallachian law began. 
